\author{
MONIKA GOLONKA \\ Polska - Poland \\ ANNA RYCHLIK \\ Polska - Poland
}

\title{
Social Entrepreneurship: rethinking theoretical assumptions
}

\begin{abstract}
Most of the Social Entrepreneurship (SE) literature derives its theoretical assumptions from the field of entrepreneurship in general, and more broadly, from modern economic theory. However, some thinkers notice significant gaps in existing theory and try to conceptualise SE incorporating some missing elements. In this theoretical paper, we explain the origins of contemporary SE concepts, analyse the significant contemporary SE works of leading thinkers and their theoretical assumptions. We also specify major shortcomings in existing concepts and demonstrate the possibility of filling gaps by realism, especially Aristotle's philosophy. His distinctive realist view of human beings, including entrepreneurs, and his broader view on economics allows us to understand the essential nature of entrepreneurship, providing unique insights regarding the intellectual-volitional faculties of the social entrepreneur.
\end{abstract}

Keywords: Aristotle; intellectual-volitional faculties; realism; social entrepreneurship; teleology; virtues

Received: 26 October 2021

Accepted: 2 December 2021

\section{Suggested citation:}

Golonka, M., Rychlik, A. (2021). Social Entrepreneurship: rethinking theoretical assumptions. Przedsiębiorczość - Edukacja [Entrepreneurship - Education], 17(2), 82-91. https://doi. rg/10.24917/ 20833296.172.6

\section{Introduction}

The term 'social entrepreneurs' was used for one of the very first times in academic papers in 1978 by Lessem when organising a Management Education Workshop. This was when he tried to find a term describing 'alternative entrepreneurs' providing an example of different types of tree in Białowieża forest (Lessem, 1978). R. Lessem perceived social entrepreneurs as "groups, institutions and activities where conventional notions of authority and the rights of ownership do not apply" (1978: 178). At the same time, a great deal of attention was focused on public entrepreneurs (e.g. Eichhorn, 1978a, 1978b; Lewis, 1980; Ramamurti, 1986; Talpaert, 1978,), and writers pointed out the major differences between regular and public entrepreneurs, e.g. public goals, organisational independence from the 
government (Ramamurti, 1986). R. Talpaert (1978) argues that social entrepreneurs are needed especially in times of crisis, as 'experimenters' with social change. He argues that managers, in all sectors of society, may become such social entrepreneurs because of the power they hold in existing organisations. He also suggests consideration of management education programs focused on educating social entrepreneurs as social 'revolutionists'. These public entrepreneurs are also called social 'catalysts of change' (Waddock, Post, 1991). C. Leadbeater (1997) considers social entrepreneurs a tool for radical social reforms (cf. Thompson, Alvy, Lees, 2000). Numerous thinkers see the role of social entrepreneurs as pioneers of social change (e.g. Ganesh, 1998) or social innovators (e.g. Leadbeater, 1997). Waddock and Post (1991) argue that social entrepreneurs are a special kind of public entrepreneur. However, as they are private citizens, not public servants, they focus on raising public awareness and developing new social solutions. Some SE writers argue that a government has a role in supporting social development (Fontan, Shragge, 1998; Gray, Healy, Crofts, 2001; Midgley, Livermore, 1998). Contemporary scholars argue that SE is a newer version of a non-profit organisation (e.g. Bale, Aziuna, 2020; Flower, 2000), while others identify SE with regular entrepreneurship (e.g. Dees, 2001; Lessem, 1978), distinguishing them only by their mission.

Analysis of the major theoretical assumptions underlying SE concepts shows that the foundation has been taken from the field of entrepreneurship, drawing from modern economic discourse. Several thinkers have noticed the significant shortcomings and gaps in existing SE concepts that call for further research. Some have tried to investigate these from elements derived from classical philosophy (e.g. Korstenbroek, Smets, 2019; Mort, Weerawardena, Carnegie, 2002).

In this theoretical study, we analyse the major concepts and assumptions, and propose to fill these gaps by incorporating an approach based on realism, Aristotelian philosophy. It explains the original meaning of the intellectual and volitional human powers, choices, the voluntarily chosen objective, and virtues. It also presents a broader view of economics, taking into account the social, psychological and moral aspects of human actions.

In the first part of the article, we describe the origins of the SE concept, while in the second one we analyse the major concepts based on the works of leading SE thinkers. In the third part, we present the results of the analysis of the theoretical assumptions behind the presented concepts and the significant gaps that exist, demonstrating the possibility of filling them by the original Aristotelian theory.

\section{Origins of the SE concept}

The rise in popularity of the SE concept in the past two decades comes from several initiatives taken by members of institutions, not the entrepreneurs themselves. The first report on social entrepreneurs was developed by the Center for Policy Research, financed by the Rockefeller Brothers Fund (Crimmins, Keil, 1983). In the report, social entrepreneurs are seen as non-profit managers, "with a background in social work, community development or business, who pursue a vision of economic empowerment through the creation of social purpose businesses intended to provide expanded opportunity for those on the margins of our nation's economic mainstream" (Schulte, 1998).

D. Richmond Gergen, Harvard University professor, former Director of Communications in the White House and an advisor to the US president, noticed the potential of 
social entrepreneurs for political and social reforms and has given his support to the rise in SE initiatives. Numerous universities (Harvard, Stanford, Columbia, New York University, Oxford, Duke) have launched initiatives supporting the concept (Dees, 2007). The World Economic Forum's founder, K. Schwab, has created the Foundation for Social Entrepreneurship and supported a public broadcasting series on the 'New Heroes' (2005), in cooperation with the Manhattan Institute, as well as created a Social Entrepreneurship Award (cf. Dees, 2007).

In the literature, SE is often considered, and promoted as alternative method of solving social problems indicated as worthy by the above institutions. "In an ideal world, social enterprises would receive funding and attract resources only when they produced their intended social impact - alleviating poverty in a given area, reducing drug abuse, delivering high-quality education, or conserving natural resources" (Dees, 1998a: 60).

$\mathrm{SE}$ is thus considered as a type of non-governmental development organisation (NGDO) (Flower, 2000). However, NGDOs themselves are considered to be political projects (Flower, 2000: 639). At present, writers recognise the possibility of transformation from traditional non-profit organisations to social enterprises to 'enhance' their activity (Bale, Aziuna, 2020; Ko, Liu, 2021). "Social enterprise is a means for non-profit agencies to maximise their mission-related performance through the development of new ventures or by reorganising activities to improve operational efficiency" (Zappalà, 2001: 43). According to Zappalà, "social enterprise is a means for non-profit agencies to maximise their mission-related performance through the development of new ventures or by reorganising activities to improve operational efficiency" (2001: 43). SE has also been seen as a 'tool for Sustainable Development' (e.g. Blanda, Urbancikova, 2020; Satyendra et al., 2021). Government and institutional funding (grants, programs etc.) are often used to finance SE initiatives (e.g. Cagarman et al., 2020; Chan et al., 2019). Recent research shows that numerous young people follow such tracks (e.g. Bublitz et al., 2021). However, writers have started to criticise such an approach, pointing out that SE is being 'used' for tackling many deep-seated and essentially 'public' structural problems (e.g. Chalmers, 2021).

Various courses, workshops, and studies in SE have been organised at universities. The leading thinkers cited in most of the literature sources in this field are Dees (cf. Zietlow, 2001, Hota et al., 2021) and Waddock and Post (Hota, Subramanian, Narayanamurthy, 2021). Their works have set up a foundation for the content of these educational courses and frame the body of present research in SE (e.g. Dees 1998a, 1998/ 2001, 2007 onward; Waddock, Post, 1991).

\section{Economic or social entrepreneur}

As Dees argues, SE has become a popular concept in part starting from the works of the New Ventures organisation "helping non-profit explore new sources of income" (Dees, 2007: 24). He sees a need "to encourage and support social entrepreneurs, individuals, and organisations that bring to social problems the same kind of determination, creativity, and resourcefulness that we find among business entrepreneurs" (Dees, 2007: 24).

Social entrepreneurs undertaking purely philanthropic entrepreneurial initiatives are characterised by Dees (1998a) as appealing to goodwill, mission and social value, while commercial entrepreneurs appeal to self-interest, the market and economic value. Another leading writer points out that "social entrepreneurs play the role of change agents in the 
social sector, by adopting a mission to create and sustain social value (not just private value)" (Zietlow, 2001). Entrepreneurial undertakings are regarded as "strategies to sustain themselves financially" (Lasprogata, Cotten, 2003). Moreover, social entrepreneurs show a set of unusual behaviours that "should be encouraged and rewarded" (Zietlow, 2001). A social entrepreneur is a person who "generates followers and commitment to the project by framing it in terms of important social values, rather than purely economic terms, which results in the sense of collective purpose" (Waddock, Post, 1991: 398, cf. Mort, Weerawardena, Carnegie, 2002). The 'sense of collective purpose' means "the interaction between the social entrepreneurs and their followers" (Waddock, Post, 1991: 399, cf. Mort, Weerawardena, Carnegie, 2002). Moreover, "the values embedded in the collective vision could be characterised as 'end values"'. The 'end values' in the thinkers' opinions, "can be stated clearly: freedom from drugs; freedom from homelessness; freedom from hunger; human dignity; health"' (Waddock, Post, 1991: 399, cf. Mort, Weerawardena, Carnegie, 2002). They are to "provide a sense of community" for members through the stated end values that draw people together (Waddock, Post, 1991: 399, cf. Mort, Weerawardena, Carnegie, 2002).

The major assumptions underlying these concepts revolve around ideas that regular entrepreneurs do not create social value (only economic, individual or private value), they do not follow a mission, or their aim is purely economic. On the other hand, social entrepreneurs do create social value, they have a mission, goodwill, show exceptional behaviours, provide end values, create community and commitment. However, social entrepreneurs use 'entrepreneurial strategies', namely economic, to sustain themselves financially, since "marketing and financial management proficiencies are key success factors" (Zietlow, 2002: 85, cf. Dees et al., 2001).

The central problem in most of the papers involves the same elements as in 'regular entrepreneurship', namely material resources, profit (or non-profit) and finance (e.g. Dees, 2001; Sroka, Meyer, 2021; Zietlow, 2002), as "an increasing number of non-profits are seeking additional revenues by behaving more like for-profit organisations". As Dees points out, "in the end, for-profit operations will not, and should not, drive out philanthropic initiatives" (Dees 1998a: 60), assuming that what drives 'regular entrepreneurs' is profit-seeking.

Such an assumption regarding entrepreneurs comes from works of several thinkers, e.g. Friedman (1970) and M. Jensen and W. Meckling (1976). However, among writers, some critics also exist of such an assumption (e.g. Dusk, 1997; Fama, 1980; Sison, 2007, Huhn, 2017). Such an approach places SE in the same economic discourse as regular entrepreneurship. Moreover, as G. Lombard (1971) noticed, incorporating social aims or values, especially in management education, often creates economic advantages in a more unclear way (cf. Golonka, 2019).

Thus, SE education content focuses primarily on, as in entrepreneurial education, revenues, business plans, funds, etc., placing SE in the same discourse of 'production', 'value', 'clients', 'strategy', 'techniques' and 'tools' (cf. Golonka, 2019). Major assumptions in the literature on SE regarding entrepreneurship come from Schumpeter, Say, Knight and Drucker (cf. Dees, 1998a, 1998b/2001), and those thinkers ground their research in philosophy of Adam Smith. The latter created the modern view on economics, focused on material wealth and consumption as the purpose of production (Smith, 1776). He replaced the classical meaning of universal good as the purpose of human actions with his 
definition of such a good, which particularised it. Thus, writers following the Smithian tradition try to define and provide the aims in SE as 'profit/non-profit' or particular 'end values' (freedom from drugs; freedom from homelessness; freedom from hunger; human dignity; health' (e.g. Waddock, Post, 1991).

Moreover, Smith focused solely on the national dimension (e.g. creating the highest possible Gross Domestic Product) instead of the developement of an individual human being in the broader sense. From this point on, the assumption taken is that human actions that do not aim at consumption (and an increase of GDP) do not create any value.

Consistently, R. Moran (1976/2011), analysing the literature on entrepreneurship, noticed that the entrepreneur as a person seems to have disappeared entirely from contemporary economic theory. Despite numerous pieces of research on entrepreneurship and $\mathrm{SE}$ in recent years considering entrepreneurs, none of them considers the internal powers and intentions of human beings that are, in fact, the origins of any external acts, including entrepreneurial ventures.

A. Smith and his many followers perceive the human individual in the light of his idea of the 'invisible hand' of the market. This idea represents displacing a person's intentionality by invoking an image of "an external agency that takes care of the matter of intentions" (Jones, 2013: 48). Thus, Moran (1976/2011) shows that the market's external 'motivating power' replaced the internal power of a person, in this case, the entrepreneur.

Consequently, in most recent articles, writers assume that entrepreneurs, including social entrepreneurs, need to be externally motivated, encouraged and rewarded (e.g. Zietlow, 2001) and given end values - pre-formulated abstract ideas to act purposefully.

Hence, following Adam Smith's ideas, the modern concept of 'motivation' was created by marketing and sales writers in the previous century in order to explain the possibility of external influence on the behaviours and actions of human beings (Danziger, 1997: 113, cf. Perrin, 1923; Tronald, 1928; Young, 1936). It results from a shift in the agency from the human to an idea-agent, accompanied by re-conceptualisation of the human internal motive for acting (Danziger, 1997, cf. Locke, 1947).

\section{Filling the gaps}

Some thinkers try to conceptualise SE, noticing the shortage of existing theory. For example, G.S. Mort et al. (2002) incorporated a 'virtue dimension' connected with a moral purpose that, in the opinion of the writers, differentiates the social from the commercial entrepreneur. They considered the Aristotelian concept of virtues "which must be acted upon to become genuine virtues"; however, they understand virtues differently than Aristotle, placing them among an entrepreneur's attitudes and behaviours and assuming that 'regular entrepreneurs' do not follow a moral purpose.

Interestingly, the thinker who reformulated the concept of Aristotle's virtues in terms of rule-following was Adam Smith (Smith, 1966). 'Self-command' (Smith, 1966, VI, 3: 349) becomes the critical virtue enabling people to control their passions. Simultaneously, he introduces into the human psychological landscape an imaginary figure of an impartial spectator' (Smith, 1966, I, 1, 5:27), whose judgment is supposed to substitute for one's intellectual judgement, a modern and reductive version of human conscience (Taylor, 1989).

Smith's ideas (especially the 'invisible hand of a market' and 'impartial spectator') have replaced the internal powers of a human being, namely Aristotelian intellectual-volitional 
faculties. Aristotle was the first philosopher to call attention to the fact that human beings are subjects with psychological faculties, enduring powers characterised by a particular kind of operation, and having a final order of worth and reverse order of development in the individual (Ross, 1923).

Aristotle was the first to understand the faculty of will, the 'rational desire/wish' (Aristotle, 1928 [Metaphysics], XII.7.1072a28). For Aristotle, will is more than 'intellectual preference,' as for Plato (Bourke, 1964). It is a rational part of the desiderative faculty, intellectual desire. Although it is a desire, it is different from a sensual or natural type. The sensual desire has as its object an 'apparent good'; the object of the ratiocinative desire is a 'real good' (Metaphysics XII.7.1072a28). Appetite is "for present pleasure mistaken for absolute pleasure and good" (Ross, 1923: 145), while rational desire is for a future good. Simultaneously, although will is rational, it is distinct from reason. It is the faculty responsible for "referring everything else to the end" (Aristotle, 1980 [NE], III.5.1114b15).

From a classical/realism perspective, each individual can recognise and choose what he/she understands as an real good as an aim/purpose of their actions using their practical wisdom. For Aristotle, practical wisdom and choice are closely related to the question of voluntary acts (NE III.2). Involuntariness, as a lack of internal autonomy to choose, is not a matter of wrong goals or lack of theoretical knowledge, but a matter of ignorance of particulars, of the circumstances and conditions on which action depends (NE III.1.1110b24). Contrarily, voluntariness is "that of which the moving principle is in the agent himself, he being aware of the particular circumstances of the action" (NE III.1.1111a13). Another realist, Thomas Aquinas, has integrated these considerations within his conceptualisation of freedom.

Consequently, he argues that the judgment to which freedom is attributed leads to a choice, not a judgment in speculative science (Quaestiones Disputatae de Veritate [QDV] Q. 24, a. 1). Freedom understood this way is not attributed to the execution of the chosen course of action as this is not always in one's power. "A man is not said to be free in his actions but free in his choice, which is a judgment about what is to be done. This is what the name free choice refers to" (QDV Q. 24, a. 1; emphasis added). Aquinas concludes that the formal character of freedom depends upon the manner of knowing, a capacity to judge one's judgement. Freedom of choice is a function of how one's own cognitive and volitional powers are perceived. It is why understanding one's psychic powers plays a significant role in the capacity to exercise free choice. "We are moved by free choice in as much as by our free choice we choose to be moved" (QDV q. 24, a. 5). If one prematurely agrees to view oneself as by nature deprived of free choice or intellectual desire in general, one gives in oneself to subjection by predetermined forces. This relationship has come to be regularly exploited by theorists starting from Adam Smith.

In realist view, practical wisdom perfects reason to the extent that the latter regulates sensual appetites and makes them consistent with intellectual desire. Aristotle, and after him Aquinas, argue that the irrational element can be peacefully persuaded by rational powers. What is necessary for the act of reason and desire to occur in practical matters is an act of choice. The object of choice is something that is in one's power. It is initiated by desire and reasoning with a view to an end. Aristotle explains that choice is right if the reasoning behind it is valid, and desire is right if the desire pursues whatever reason asserts (NE VI.2.1139a22). Aristotle defines choice as "either desiderative reason or ratiocinative desire" (NE VI.2.1139b), which shows that it constitutes an act distinct from acts 
of natural and sensuous appetites (see Bourke, 1964).

In a practical inquiry, an act of choice is preceded by an act of decision, the judgment about what has been deliberated upon. Only after a person has decided, can he/she make a choice, an act of will to take a particular course of action (QDV q. 22, a. 15, ad 2). Thus, choice constitutes an origin of external acts. It shares in the characteristics of prudence (QDV, q. 22, a. 15, ad 3). Making the right choice in practical matters requires that one has practical wisdom and moral virtues "for virtue makes the goal correct, and practical wisdom makes what leads to it correct" (NE VI.12.1144a6-10). Aristotle's ethics and psychology are related to teleology (from Greek telos' end' and logos 'reason') (Wozniak, 2020). It implies that the meaning and nature of any person, community or thing are derived from the end of their being (Ross, 1923).

Thus, the aim voluntarily recognised and chosen by a human being is crucial for any person, including an entrepreneur. However, Aristotle recognises teleology in its internality as "an immanent end, in working towards which the members of a scheme are united to one another in common participation” (Wozniak, 2020, cf. Barker, 1906: 227). The teleological category of the reason for action has been substituted in modern literature by the category of 'motive' pushing a person into activity (Danziger, 1997: 44-45). Contrary to Aristotle's view, it is no longer an end that attracts one's will and draws a person to action.

Intellectual-volitional interpenetration has been suspended in the works of a majority of entrepreneurship thinkers and the SE field. However, such an interpretation helps fill the gaps and resolve major problems observed by SE thinkers. Both regular and social entrepreneurs, as human beings, can use their internal powers (intellect and will) in order to recognise a real good as his/her aim (end), depending on the unique situation and the abilities of the person, choose it and undertake actions toward achieving it (Golonka, 2021). Acts of decisions and choices of real good, using the intellect and will, perfect the person and allow him/her to become genuinely virtuous. Contrary to Aristotle's view, it is no longer an end that attracts one's will and draws a person to action.

Moreover, Aristotle's teleology shows that the aim, rationally and voluntarily recognised, and chosen by different individuals, actually 'unites' them in joint participation towards achieving it, which implies formation of a real community instead of arranging a 'sense of community' by formulating 'end values' (cf. Waddock, Post, 1991). As T. Aquinas explains, the result of such genuine cooperation, a unity of rational human desires in consenting to the same thing (Aquinas, 2006; cf. Golonka, 2021), is a harmonious, peaceful community. In such a case any external methods of 'motivation', creating an exceptional environment or providing 'values', are useless.

Since 1970's, writers have noticed that the division between 'business' and 'social' enterprise is becoming increasingly fluid (cf. Lessem, 1978). This blurring division can also be understood by incorporating the Aristotelian view of a human being and the original meaning of economy: Oikos and Nomos (from Greek, meaning management of family, property, house). Aristotle understands the economy in much broader sense than Adam Smith and his followers. For the Greek philosopher, the economy is the art of earning a living, accompanied by the art of building social relationships and the art of self-development leading to excellence. Such excellence in individuals constitutes actual socio-economic development, also in the national dimension. 
In this paper, we have provided an analysis of SE definitions in the literature, the origins of the concept, and the significant gaps in the existing theory. Several thinkers have tried to fill the gaps by incorporating the classical view on the human being. We have discussed the SE field's theoretical assumptions and explained major discrepancies between the SE intellectual tradition, following Smithian ideas, and the classical, namely realistic perspective on a human being and socio-economic development. A major problem in existing theory are constituted by the theoretical assumptions disregarding internal powers and internal teleology. We have incorporated realistic Aristotelian-Thomistic interpretation, that offers a more comprehensive view on the development of a human being and human actions, including entrepreneurial ventures. It highlights the meaning of an aim (in more general terms than the views presenting aim as the narrow, consumption-oriented objectives), intellectual-volitional faculties (intellect, and rational desire - will), choices, practical wisdom, virtues, and explains the actual, as observed in socio-economic reality, the interconnection between the economic, social, psychological and moral aspects of human actions. In order to reveal the full scope of the consequences of misrepresenting and disregarding the realist theoretical tradition, further research is required. Realist Aristotelian-Thomistic philosophy opens a whole new field worthy of comprehensive investigation for thinkers and students interested in the question of human entrepreneurial actions.

\section{References}

Aristotle. (1928). Metaphysics (D. Ross, Trans.). In: D. Ross (Ed), The Works of Aristotle. Vol. VIII. Oxford: The Clarendon Press.

Aristotle. (1980). The Nicomachean ethics (D. Ross, Trans.). Oxford: Oxford University Press.

Aquinas, T. (2006). ST. Charity. Vol. 34. Cambridge: Cambridge University Press.

Aquinas, T. (1952-54). Quaestiones Disputatae de Veritate (Truth) (R.W. Mulligan, J.V. McGlynn, R.W. Schmidt, Trans.). Chicago: Henry Regnery Company. Retrieved from: https://dhspriory.org/ thomas/english/QDdeVer.htm

Bale, I., Auzina, A. (2020). Economic Science for Rural Development. Conference Proceedings, 53, 139 147. https://doi.org/10.22616/ESRD.2020.53.016

Blanda, J., Urbančíková, N. (2020). Social Entrepreneurship as a Tool of Sustainable Development. Quality Innovation Prosperity, 24(3), 21-36. https://doi.org/10.12776/QIP.V24I3.1463

Bourke, V.J. (1964). Will in Western Thought. New York: Sheet and Ward.

Bublitz, M.G., Chaplin, L.N., Peracchio, L., Cermin, A., Dida, M., Escalas, J., Eilert, M., Gloukhovtsev, A., Mille, E. (2021). Rise Up: Understanding Youth Social Entrepreneurs and Their Ecosystems. Journal of Public Policy \& Marketing, 40(2), 206-225.

Chalmers, D. (2021). Social Entrepreneurship's Solutionism Problem. Journal of Management Studies, 58(5), 1363-1370.

Cagarman, K., Kratzer, J., von Arnim, L.H., Fajga, K., Gieseke, M. (2020). Social Entrepreneurship on Its Way to Significance. Sustainability, 12, 8954. Received from: https://www.mdpi.com/2071$1050 / 12 / 21 / 8954$

Chan, C.C., Chui, C., Chan, K., Yip, P., Siu, F. (2019). Social Policy \& Administration, 53(6), 903-919. https://doi.org/10.1111/spol.12524

Crimmins, J.C., Keil, M. (1983). Enterprise in the Non-Profit Sector. New York: Rockefeller Brothers Fund.

Danziger, K. (1997). Naming the mind: How psychology found its language. London: Sage Publications. http://doi.org/10.4135/9781446221815 
Dees, J.G. (2016). Social Entrepreneurship. https://doi.org/10.1057/978-1-349-94848-2_373-1

Dees, J.G. (2011). Social Ventures as Learning Laboratories. Tennessee's Business, 20(1), 3-5.

Dees, J.G. (2007). Taking Social Entrepreneurship Seriously. Society, 44(3), 24-31.

Dees, J.G. (1998a). Enterprising Nonprofits. Harvard Business Review, 76(1), 54-66.

Dees, J.G. (1998b/2001, 12 July). The Meaning of 'Social Entrepreneurship'. Retrieved from: https://www. academia.edu/7911863/The_Meaning_of_Social_Entrepreneurship_

Dees, J.G., Emerson, J., Economy, P. (2001). Enterprising Nonprofits: A Toolkit for Entrepreneurs. Hoboken, N.J.: Wiley.

R.E. (1997). The why's of business revisited. Journal of Business Ethics, 16(12/13), 1401-1409.

Eichhorn, P. (1978a). Public Enterprise in Germany. Definition Ownership, Objectives and Control. Univ. Of Mannheim.

Eichhorn, P. (1978b). Public Enterprise in the EEC. Part III. Federal Republic of Germany, edited by William Keyser and Ralph Windle, Sijthoff \& Noordhoff, The Netherlands.

Fama, E.F. (1980). Agency problems and the theory of the firm. Journal of Political Economy, 88(2), 288-307.

Flower, A. (2000). NGDOS as a moment in history: beyond aid to social entrepreneurship or civic innovation?. Third World Quarterly, 21(4), 637-654.

Fontan, J., Shragge, E. (1998). Community economic development organisations in Montreal. In: M.S. Sherraden, W.A. Ninacs, (eds.), Community Economic Development and Social Work. New York: Haworth Press.

Friedman, M. (1970). The social responsibility of business is to increase its profits. The New York Times Magazine (13 September).

Ganesh, P.N. (1998). Social entrepreneurial leadership. Career Development International, 4(3), 140-145.

Golonka, M. (2021). Coworking vs Corpoworking: Realistic Perspective. In: M. Orel et al. (eds.), The Flexible Workplace, Human Resource Management, 97-112.

Golonka M. (2019). Entrepreneurship Education - a Realistic Perspective. Przedsiębiorczość - Edukacja [Entrepreneurship - Education], 15(2), 40-58.

Gray, M., Healy, K., Crofts, P. (2001). Social Entrepreneurship: Whose responsibility is it anyway? Paper presented to the Social Entrepreneurship Workshop Centre for Full Employment and Equity and the Department of Social Work The University of Newcastle 21 November 2001

Hota, P.K., Subramanian, B., Narayanamurthy, G. (2020). Mapping the Intellectual Structure of Social Entrepreneurship Research: A Citation/Co-citation Analysis. Journal of Business Ethics, 166, 89114.

Huhn, M. (2017). Responsible Innovation: a Smithian Perspective. Philosophy of Management, 17, 41-57.

Jensen, M., Meckling, W. (1976). Theory of the firm: managerial behavior, agency costs and ownership structure. Journal of Financial Economics, 3, 305-360.

Ko, W., Liu, G. (2021). The Transformation from Traditional Nonprofit Organisations to Social Enterprises: An Institutional Entrepreneurship Perspective. Journal of Business Ethics, 171(1), 15-32. https://doi.org/10.1007/s10551-020-04446-z

Korstenbroek, T., Smets, P. (2019). Developing the Potential for Change: Challenging Power Through Social Entrepreneurship in the Netherlands. International Journal of Voluntary \& Nonprofit Organisations, 30(3), 475-486.

Lasprogata, G.A., Cotton, M.N. (2003). Contemplating "Enterprise': the business and legal challenges of social entrepreneurship. American Business Law Journal, 41, 67-113.

Leadbeater, C. (1997). The Rise of the Social Entrepreneur. London: Demos.

Lessem, R. (1978). Towards the Interstices of Management: Developing the Social Entrepreneur. Workshop: Management Education and Development, 9, 178-188.

Lewis, E. (1980). Public Entrepreneurship: Toward a Theory of Bureaucratic Political Power. Bloomington: Indiana University Press.

Lombard, G. (1971). Relativism in organisations. Harvard Business Review, 49(2), 55-65. 
Mort, G.S., Weerawardena, J., Carnegie, K. (2002). Social entrepreneurship: Towards conceptualisation. International Journal of Nonprofit and Voluntary Sector Marketing, 8(1), 76-88.

Midgley, J., Livermore, M. (1998). Social capital and economic development: Implications for community-building practice. In: M.S. Sherraden, W.A. Ninacs (eds.), Community Economic Development and Social Work. New York: Haworth Press.

Moran, R. (1976/2011). Social responsibility, entrepreneurship, and the goals of firms: An examination of current economic literature. Forum for Social Economics Vil., 6(2).

Perrin, F.A.C. (1923). The psychology of motivation. Psychological Review, 30, 176-191.

Ramamurti, R. (1986). Public Entrepreneurs: Who They Are and How They Operate. California Management Review, XXVIII(3), 142-158.

Ross, W.D. (1923). Aristotle. London: Methuen.

Satyendra, P., Swati, P., Scott, W., Eric, W. (2021). CSR and social entrepreneurship: Combining efforts towards sustainability. Journal of Global Scholars of Marketing Science, 30(4), 335-343.

Schulte, L.S. (1998). JWOD CRP's: social entrepreneurs and the business of rehabilitation. American Rehabilitation, 24(1), 2-8.

Sison, A.J.G. (2007). Toward a common good theory of the firm: The Tasubinsa case. Journal of Business Ethics, 74(4), 471-480.

Smith, A. (1966). The Theory of Moral Sentiments. New York: A.M. Kelley.

Smith, A. (1776/2020). Wealth of Nations. Harriman House Publishing.

Sroka, W., Meyer, N. (2021). A theoretical analysis of social entrepreneurship: The case of Poland and South Africa. Journal of Eastern European \& Central Asian Research, 8(1), 133-148.

Talpaert, R. (1978). Management in Modern Society: A Pro-Active Approach. Management Learning, 9, 139-150.

Thompson, J., Alvy, G., Lees, A. (2000). Social entrepreneurship - a new look at the people and the potential. Management Decision, 38(5), 328-338.

Tronald, L.T. (1928). The Fundamentals of Human Motivation. New York: Van Nostrand (Reprinted Hafner, New York, 1967).

Waddock, S.A., Post, J.E. (1991). Social Entrepreneurs and Catalytic Change. Public Administration Review, 5I(5), 393-401.

Wozniak, A. (2020). The misconducts of UN peacekeepers as an unintended consequence of the Kantian law-based ethics and moral psychology: an Aristotelian analysis. Science \& Peace, XI(1), 85-99.

Young, P.T. (1936). Motivation of Behavior: The Fundamental Determinants of Human and Animal Activity. New York: Wiley.

Zappalà, G. (2001). From 'charity' to 'social enterprise': Managing volunteers in public-serving non-profits. Australian Journal on Volunteering, 6(1), 41-48.

Zietlow, J.T. (2001). Social Entrepreneurship: Managerial, Finance and Marketing Aspects. Journal of Nonprofit and Public Sector Marketing, 9(1), 19-44.

Monika Golonka, $\mathrm{PhD}$ habilited. Author's research interests revolve around areas of organization, realism, autonomy and freedom in creative and intellectual work.

ORCID: https://orcid.org/0000-0001-8312-454

\section{Adres/Address:}

e-mail: monika.golonka@protonmail.com

Anna Rychlik, PhD. Author's research interests revolve around areas of organization, realism, autonomy and freedom in creative and intellectual work. 